\title{
Impact of Covid-19 on the media system. Communicative and democratic consequences of news consumption during the outbreak
}

\author{
Andreu Casero-Ripollés
}

Nota: Este artículo se puede leer en español en:

http://www.elprofesionaldelainformacion.com/contenidos/2020/mar/casero_es.pdf

How to cite this article:

Casero-Ripollés, Andreu (2020). "Impact of Covid-19 on the media system. Communicative and democratic consequences of news consumption during the outbreak". El profesional de la información, v. 29, n. 2, e290223. https://doi.org/10.3145/epi.2020.mar.23

Manuscript received on 15th April 2020 Accepted on 24th April 2020

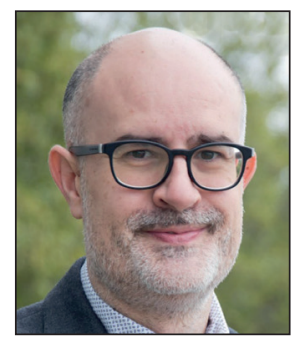

Andreu Casero-Ripollés

https://orcid.org/0000-0001-6986-4163

Universitat Jaume I de Castelló

Departamento de Ciencias de la Comunicación

Facultad de Ciencias Humanas y Sociales

Avda. Vicent Sos Baynat, s/n. 12071 Castelló, Spain

casero@uji.es

\begin{abstract}
Covid-19 is a phenomenon of enormous magnitude and relevance. Its impact has affected various social domains, including the media and journalism. Since the beginning of this health crisis, the news has become a valuable resource for citizens. Studying the dynamics of information consumption is highly relevant both for its ability to transform the media system and for its incidence in democracy. The objective of this research is to analyse the influence of the new coronavirus on news consumption, the credibility given by citizens to the media as well as their ability to detect fake news. To answer these questions, we have conducted an exploratory analysis based on the secondary data from the online surveys of the Pew Research Center's American Trends Panel in the United States, comparing data before and after the outbreak. The results confirm the impact of Covid-19 on the media system. The findings suggest the emergence of important developments such as the resurgence of the role of legacy media, especially television, and the fact that citizens who usually remain far from the information have reconnected with the news. Therefore, the existing inequalities regarding news consumption among citizens have been reduced, in part. This generates potential benefits for democracy in terms of equality and accessibility concerning public affairs.
\end{abstract}

\section{Keywords}

Covid-19; Coronavirus; Media system; News consumption; Social media; Legacy media; Political communication; Fake news; Credibility; Reliability; Democracy; Journalism.

\section{Funding}

This article is part of the research project CSO2017-88620-P, funded by the Spanish Research Agency (AEI) of the Government of Spain within the National Plan for R\&D, and the research project UJI-B2017-55, funded by the Universitat Jaume I de Castelló within the 2017 Research Promotion Plan.

\section{Acknowledgment}

The author wishes to express his gratitude to the Pew Research Center for allowing access to data. The views expressed in this article, including the political implications, are those of the author and not the Pew Research Center. 


\section{Introduction}

Covid-19 is having important and profound effects in several spheres of our society. It has affected the news, journalism, and the media system, among other domains. In mid-March 2020, the state of emergency was declared in the event of a health crisis. Since then, information on the outbreak has become a precious and valuable asset to face the situation.

The enormous importance of Covid-19 throughout the planet makes it a highly relevant event to study the transformations in the media as a result of its impact. For this reason, here we propose an exploratory and initial study to provide the first evidence on how it has conditioned the dynamics of the media system and how it has affected democracy. The analysis focuses on the United States, one of the countries in the world with the more developed media system which has been hugely damaged by the pandemic. Information practices have important repercussions not only in the knowledge citizens have of their immediate reality, but also in democratic terms, due to the close links between information and democracy. Therefore, studying information is key, especially at highly significant moments for our society, such as the Coronavirus outbreak.

\section{Literature review}

Information is a fundamental resource for citizens in our society. It is a valuable mechanism for guiding people, especially in highly complex situations such as the one generated by the Covid-19 pandemic. In this sense, information is a tool that can help reduce uncertainty and anxiety. Conversely, it might increase panic and chaos.

Likewise, information enables us to know what is going on around us. Moreover, it allows us access to current events and public affairs that may affect our daily life. Therefore, it is a key tool for the functioning of a healthy democracy. Providing quality information to citizens allows them to form an opinion and participate politically. In fact, this is the primary purpose of journalism (Kovach; Rosenstiel, 2007) and one of the central elements of its conception. By providing news, journalism becomes essential for the articulation of the public sphere, which functions as an independent and intermediary system between the State and society in liberal democracies, guaranteeing the principle of general access to information for all citizens (Habermas, 2006). The news thus becomes a vital product for civic life.

In consequence, news consumption is a crucial process to promote an informed citizenry committed to public affairs. How people obtain information about relevant current events is important because it can have democratic consequences (Feenstra et al., 2016). This may create divisions between informed and misinformed citizens, causing inequalities and imbalances that affect the principle of intrinsic equality, which is a premise for democracy (Dahl, 2006).

However, not all media stimulate information opportunities, political interest and knowledge, and participation in civic life in the same way. In recent decades, with the emergence and consolidation of digital technologies, the media system has experienced numerous transformations (Casero-Ripollés, 2018). Thus, a complex system has been created which is characterised by the proliferation of channels and platforms, the multiplication of information providers, the abundance of communication, and the increase in competition among the media. As a result, a saturated news ecosystem has emerged where being informed is not an easy task. Increased disinformation (Bennett; Livingston, 2018), mistrust towards legacy media, political polarisation, fragmentation, and the configuration of a high-choice media environment (Van-Aelst et al., 2017) make it difficult for citizens to obtain valuable information on public affairs.

The rise of fake news indicates the collapse of the traditional news order and the chaos of contemporary public communication

A major obstacle is a rise in the circulation of fake news, spreading hoaxes and falsehoods among citizens. Fake news is fabricated information that astutely imitates regular news and takes advantage of existing public beliefs to influence and destabilise society and institutions, generating confusion and anxiety among citizens (Waisbord, 2018). Social media have generated unprecedented scale and speed in the dissemination of this type of made-up news. Its rise indicates the collapse of the traditional news order and the chaos of contemporary public communication (Waisbord, 2018). The loss of trust in political institutions is associated with disaffection. Along with it, misinformation originates from loss of credibility in legacy media. This causes the spread of misinformation and enhances its effects on credulous citizens. This phenomenon is also associated with the growth of alternative sources of information linked to populism and the radical right that pursue geopolitical objectives and interests, by generating chaos and confusion through information (Bennett; Livingston, 2018). Therefore, its consequences are highly damaging to democracy.

In this context of changes, the political information environment is established. It is described as a mediated public space through which information flows (Esser et al., 2012). It has two dimensions: supply, related to the quantity and quality of news on public affairs provided to citizens, and demand, which includes the consumption habits of the public and their attitudes towards the news. These two dimensions influence both the information that reaches citizens, their diet and their information practices. This also conditions their political knowledge, their opinions, their political participation, and their civic and electoral behaviour.

Traditionally, television has played a key role in the political information environment (Esser et al., 2012). From the mid20th century, this medium has been at the heart of political and cultural life in many democracies. Television has been 
the great mass media that functioned as a social link capable of uniting the political community around the main topics of public interest with the news (Wolton, 1990). However, the rise of digital media has eroded its preponderance, opening a crisis about its place and relevance in the media system.
The emergence of new consumption ha-

bits is changing the way citizens attribute relevance to public affairs

This process is affecting television and the rest of the legacy media, such as print newspapers. In recent years, these media have seen their audience, income, and credibility drop drastically. Their journalistic authority understood as the right to be heard, is being questioned and challenged, being their work and social relevance at risk (Carlson, 2017). Likewise, their influence on the social media conversation has been reduced and they have been forced to share the leading role in the digital public sphere with other social actors (Casero-Ripollés, 2020). So far, all these facts challenge their hegemonic power.

Likewise, legacy media are losing their pre-eminence as the main source of information for citizens on public affairs (Bennett; Pfetsch, 2018). The emergence of new consumption habits is changing the way citizens attribute relevance to current affairs. On the one hand, more people obtain information to form their own opinion, from places linked to infotainment or political satire, which are distant from hard news (Williams; Delli-Carpini, 2011). On the other hand, the number of people accessing information through social media and mobile instant messaging services is growing (Newman et al., 2019). This implies profound changes in the way we inform ourselves. The main belief is that one can be well informed through peers and virtual networks without the need to actively search for information, and without paying regular attention to the professional media, simply hoping that the news finds me (Gil de Zúñiga; Weeks; Ardèvol-Abreu, 2017). This type of incidental consumption causes people that use social media to inform themselves to have lower political interest and less knowledge about public affairs (Gil de Zúñiga; Diehl, 2019; Lee; Xenos, 2019). This highlights the limits of social media to generate a well-informed and civically engaged citizenship (Gil de Zúñiga; Huber; Strauß, 2018).

However, the consolidation of the use of digital platforms for information has generated the configuration of a hybrid media system, where old and new media coexist (Chadwick, 2017). They interact and interrelate, sometimes harmonically and sometimes in conflict, shaping the current political information environment and the increasingly digitalised public sphere. This hybridisation between legacy and digital media enhances the complementarity between media. Instead of conceptualising themselves as opposed to each other, people perceive themselves as complementary in the information gathering process (Dutta-Bergman, 2004). Citizen interest is directed towards content, not the media. Therefore, they use a combination of different media outlets to obtain the information they seek or need.

In this context, we are in the midst of a process of a profound transformation of both the media system and the role of the media in society and democracy. For this

Citizen interest is directed towards content, not the media reason, it is essential to study how news consumption patterns work and what conception citizens hold about their practices when obtaining information. An event of great public relevance, such as Covid-19, offers a unique opportunity to study these issues and their impact on both the media system and democracy.

\section{Objectives and methodology}

The specific objectives of this research are:

01. To know the incidence of Covid-19 in how citizens consume news.

O2. To examine the impact of news about the Coronavirus outbreak on citizens' credibility on the media.

O3. To explore citizens' ability to detect fake news related to Covid-19.

O4. To analyse the communicative and democratic consequences of citizens' informative practices during the Covid-19.

The data used to reach these objectives, employing the comparative analysis of secondary data, was obtained from the American Trends Panel of the Pew Research Center. This online survey with a longitudinal design and closed-ended questions analyse the attitudes, values, and behaviours of North American citizens concerning relevant public affairs. It has been conducted since 2014 to people over 18, who live in the United States.

Specifically, for the applied comparative analysis, three waves of the American Trends Panel (ATP) have been used:

1) Wave 57. This survey was conducted from October 29, 2019 to November 11, 2019. The final sample of responses was 12,043 people. The margin of sampling error for weighted estimates based on the full sample is \pm 1.43 percentage points ( $95 \%$ confidence level). From this panel wave, the variable "trust in news media" has been used to measure the average credibility prior to the Coronavirus outbreak.

2) Wave 62: This survey was conducted from February 18, 2020 to March 2, 2020. The final sample of responses was 
10,300 people. The margin of sampling error for weighted estimates based on the full sample is \pm 1.48 percentage points ( $95 \%$ confidence level). From this wave of the panel, the variables "follow news about candidates for the 2020 presidential election" have been extracted to analyse the consumption of news on a relevant public issue before the Coronavirus outbreak, and "has seen political news that seemed made-up ", to measure citizens' ability to detect fake news before the start of the Covid-19 crisis.

3) Wave 63.5: This survey was conducted from March 10, 2020 to March 16, 2020. The final sample of responses was 8,914 people. The margin of sampling error for weighted estimates based on the full sample is \pm 1.60 percentage points ( $95 \%$ confidence level).

The data refer to the impact of Covid-19 on citizens' informative practices. The following variables have been extracted from this wave of the panel: "follow news about the Coronavirus outbreak" to measure news consumption, "how well the media have covered the outbreak" to measure media credibility, and "has seen the news about the Coronavirus that seemed made-up" to measure the detection capacity of fake news.

Therefore, three dependent variables have been selected:

- Frequency of news consumption. Two categories have been used and added: very closely and fairly closely.

- Media credibility evaluation. Two categories have been used and added: very well and somewhat well.

- Fake news detection frequency. Two categories have been used and added: a lot and some.

Among these variables, only the categories related to positive responses or higher frequencies of use have been considered for analysis, disregarding negative or lower responses. These categories have been grouped into a single category per variable. Thus, for example, in the variable related to news following (consumption), only the categories "very" and "fairly close" were considered, and they were added in a single one. On the other hand, the categories "not too close" and "not at all closely", which indicate low or no levels of news consumption, have been discarded. A comparative analysis has been conducted between the data before the health emergency (waves 57 and 62) and the data after which correspond to the initial period of the Coronavirus outbreak (wave 63.5). This way, the impact of this health crisis has been analysed.

In the three waves, five independent variables have been used. Two of a sociodemographic nature, two associated with types of news consumers, and one related to the preferred access platform to the news. These are the following:

- Age. It is divided into 4 categories: 18-29, 30-49, 50-64, and 65+.

- Education. It is divided into 4 categories: High school or less, Some college, College graduate and Postgraduate.

- News engagement. It is divided into 3 categories: news influencers (those who say they follow news very or somewhat closely and say they tend to lead more than listen during conversations about politics and public affairs), news bystanders (follow news very or somewhat closely or lead political conversations), and those who ignore election news (neither follow political news closely nor lead political conversations).

- Attention to the news. It is divided into 4 categories: Very closely, somewhat closely, not too close and not at all closely.

- The platform used for news. 5 categories have been selected: print (including newspapers), network TV, cable TV, social media, and website or app.

\section{Results}

\subsection{News consumption during the Covid-19 outbreak}

The declaration of the state of emergency to stop the spread of Covid-19 greatly increased citizens' consumption of information. In the United States, the percentage of people who closely followed news about the Coronavirus increased by 32 percentage points during the second half of March 2020, compared to the tracking of political news data from the previous fortnight. Thus, $57 \%$ of US adults followed the news about Covid-19 "very closely" and 35\% "fairly closely". In total, $92 \%$ of citizens actively consumed news about the virus, compared to $8 \%$ who consumed news sporadically.

The analysis by variables of news consumption during the beginning of the Coronavirus outbreak enables us to observe interesting findings. Considering citizens' news engagement, a substantial increase of $62 \%$ is detected in those usually ignoring the news if we compare the data before and after the declaration of the state of emergen-
During the start of the outbreak, news consumption increased $62 \%$ among people who are normally the less close to them 
cy (Table 1). Within the categories of citizens most engaged with the news, growth is lower, but consumption values close to $100 \%$ of the population (98\% and 96\%) are detected. These figures reveal a high degree of news consumption generated by the Covid-19. Moreover, the higher the level of news engagement, the higher the percentage of people consuming news both before and after the pandemic.

News consumption grew extraordinarily, especially among those people less informed, due to Covid-19. This fact becomes evident if we introduce the variable of attention to the news in the analysis. Here, again, those citizens usually disconnected from the news (not very close and not at all closely) were the ones who experienced a major increase in news consumption due to the Coronavirus outbreak. The data show a substantial rise of 61 and $66 \%$, respectively (Table 2 ). As in the previous variable, citizens who normally consume news almost reached universal consumption with the arrival of the pandemic ( $99 \%$ and $97 \%$ ). Also, the data indicate that while the attention to the news increases, the percentage of citizens who consume news grows.

When introducing the age variable, we can see how the Coronavirus outbreak caused a notable consumption increase of news in younger citizens. Thus, the percentage of people between 18 and 29 years old who consumed news grew by 47 points between before and after the declaration of the state of emergency (Table 3). Before the crisis, only $39 \%$ of young people consumed political news frequently. A figure that rose to $86 \%$ with the health crisis. As a result, differences among different age groups regarding news consumption decreased in the context of Covid-19. But the data indicate that as age increases, the percentage of people consuming news increases. Thus, in older age ranges, the values suggest that news consumption about the pandemic is almost universal.
Table 1. News consumption based on news engagement by citizens (\%)

\begin{tabular}{|l|c|c|c|}
\hline \multicolumn{1}{|c|}{ News engagement } & Pre-Covid-19 & Covid-19 & Difference \\
\hline News influencers & 88 & 98 & +10 \\
\hline News bystanders & 76 & 96 & +20 \\
\hline Those checked out of news & 22 & 84 & +62 \\
\hline Total U.S. adults & 60 & 92 & +32 \\
\hline
\end{tabular}

Table 2. News consumption based on citizens' attention to the news (\%)

\begin{tabular}{|l|c|c|c|}
\hline \multicolumn{1}{|c|}{ Attention to the news } & Pre-Covid-19 & Covid-19 & Difference \\
\hline Very closely & 96 & 99 & +3 \\
\hline Somewhat closely & 73 & 97 & +24 \\
\hline Not too closely & 29 & 90 & +61 \\
\hline Not at all closely & 9 & 75 & +66 \\
\hline Total U.S. adults & 60 & 92 & +32 \\
\hline
\end{tabular}

Table 3. News consumption according to citizens' age (\%)

\begin{tabular}{|l|c|c|c|}
\hline \multicolumn{1}{|c|}{ Age } & Pre-Covid-19 & Covid-19 & Difference \\
\hline $18-29$ & 39 & 86 & +47 \\
\hline $30-49$ & 51 & 90 & +39 \\
\hline $50-64$ & 66 & 95 & +29 \\
\hline $65+$ & 81 & 97 & +16 \\
\hline Total U.S. adults & 60 & 92 & +32 \\
\hline
\end{tabular}

Table 4. News consumption according to citizens' education (\%)

\begin{tabular}{|l|c|c|c|}
\hline \multicolumn{1}{|c|}{ Education } & Pre-Covid-19 & Covid-19 & Difference \\
\hline High school or less & 51 & 89 & +38 \\
\hline Some college & 58 & 92 & +34 \\
\hline College graduate & 66 & 95 & +29 \\
\hline Postgraduate & 74 & 96 & +22 \\
\hline Total U.S. adults & 60 & 92 & +32 \\
\hline
\end{tabular}

Table 5. News consumption regarding the platform citizens use to access the news (\%)

\begin{tabular}{|l|c|c|c|}
\hline \multicolumn{1}{|c|}{ Platform } & Pre-Covid-19 & Covid-19 & Difference \\
\hline Print & 67 & 93 & +26 \\
\hline Network TV & 69 & 96 & +27 \\
\hline Cable TV & 74 & 96 & +22 \\
\hline Social media & 38 & 87 & +49 \\
\hline Website or app & 66 & 94 & +28 \\
\hline Total U.S. adults & 60 & 92 & +32 \\
\hline
\end{tabular}

The data from the European context also reveal a significant increase in news consumption by young people. The consumption by young people of the evening news of European public television grew by $20 \%$ during the start of Covid-19 $(E B U, 2020)$. In Spain, when the health emergency started, television consumption of this age group was $59.6 \%$ (Barlovento, 2020) and $72 \%(G f k, 2020)$ concerning the digital press.

Concerning education, Covid-19 caused an increase in news consumption of citizens with low educational levels. There was an increase of 38 and 34 percentage points in the least educated categories (Table 4). This group almost reached the consumption levels of the more educated people. However, the education level continued to affect news consumption, 
both before and after the Coronavirus outbreak. As a result, the percentage of citizens who frequently consume news increases as their education increases.

The analysis of news consumption concerning the platform used to access information enables us to observe an augment in all the media. Social media achieved the largest increase with 49 percentage points (Table 5). The rise in the rest was at similar levels. However, television (network and cable) achieved the highest percentages of frequent news consumption (96\%). Despite its growth, social media ranked last (87\%), surpassed by print media (93\%).

Covid-19 has given relevance to television. According to Nielsen, the overall increase in television viewing during the first few weeks of the outbreak is estimated to be $60 \%$ in the United States.

https://www.nielsen.com/us/en/insights/article/2020/staying-put-consumers-forced-indoors-during-crisis-spend-moretime-on-media

Specifically, the evening news on TV networks recorded an average increase in the audience of $42 \%$ compared to the same period a year earlier (Koblin, 2020). On the other hand, cable news gained $92 \%$ of the audience in comparison with the beginning of 2020, according to data from the consulting firm Alphonso.

https://alphonso.tv

In other countries, this trend happened likewise. According to data from the European Broadcasting Union (2020), the evening news audience on European public television increased by $14 \%$ at the start of the Covid-19 crisis in Europe compared to the figures recorded in early 2020. In Spain, television consumption increased to $37.8 \%$ after the declaration of the state of alarm (Barlovento, 2020). While the healthcare situation was getting worse, the audience reached the highest peak registered since 1992, the year that television audiences began to be measured in Spain.

\subsection{Credibility in media coverage during Covid-19}

The rise in news consumption came together with a slight improvement in the positive assessment of the media coverage, associated with credibility. Thus, those Americans who positively valued the media reporting activity on Covid-19 stood at $70 \%$, which involved a rise of $4 \%$ from the data recorded before the health crisis. Despite this, the data suggest that the increased consumption of news about Coronavirus did not translate into a significant increase in trust towards the media.

Considering the news engagement of citizens, we detected an increase of 12 percentage points in the least connected citizens when it comes to positively assessing the media coverage of the Covid-19 (Table 6). The rest did not register any substantive changes. But those committed users reduced their rating by one point about the media's informative work.

A similar trend is detected when analysing the variable of attention to the news. Those who normally avoid consuming information increased their positive assessment of the media coverage about the health crisis. Specifically, citizens who used to be "not at all closely" to the news raised favourable assessment by 21 percentage points, going from $40 \%$ to $69 \%$ (Table 7). As in the previous variable, user groups most connected to the news did not increase their percentages of positive assessment with the arrival of the Covid-19. Those in the category "somewhat closely" reduced their favourable assessment by one point.

The set of variables related to engagement and attention to the news regarding credibility in the media coverage shows that the Coronavirus outbreak caused an unprecedented effect. It generated higher percentages of positive
Table 6. Positive assessment of the media coverage based on news engagement (\%)

\begin{tabular}{|l|c|c|c|}
\hline \multicolumn{1}{|c|}{ News engagement } & Pre-Covid-19 & Covid-19 & Difference \\
\hline News influencers & 67 & 66 & -1 \\
\hline News bystanders & 70 & 72 & +2 \\
\hline Those checked out of news & 59 & 71 & +12 \\
\hline Total U.S. adults & 66 & 70 & +4 \\
\hline
\end{tabular}

Table 7. Positive assessment of the media coverage based on citizens' attention to the news (\%)

\begin{tabular}{|l|c|c|c|}
\hline \multicolumn{1}{|c|}{ Attention to the news } & Pre-Covid-19 & Covid-19 & Difference \\
\hline Very closely & 67 & 69 & +2 \\
\hline Somewhat closely & 72 & 71 & -1 \\
\hline Not too closely & 63 & 70 & +7 \\
\hline Not at all closely & 48 & 69 & +21 \\
\hline Total U.S. adults & 66 & 70 & +4 \\
\hline
\end{tabular}

Table 8. Positive assessment of the media coverage according to citizens' age (\%)

\begin{tabular}{|l|c|c|c|}
\hline \multicolumn{1}{|c|}{ Age } & Pre-Covid-19 & Covid-19 & Difference \\
\hline $18-29$ & 62 & 62 & 0 \\
\hline $30-49$ & 68 & 68 & 0 \\
\hline $50-64$ & 65 & 74 & +9 \\
\hline $65+$ & 64 & 76 & +12 \\
\hline Total U.S. adults & 66 & 70 & +4 \\
\hline
\end{tabular}


assessment among those people furthest away from news consumption than among regular consumers. They were more critical of the informative role of the media during the crisis.

The media assessment analysis by age presents several interesting facts. First, only groups of elderly people experienced changes before and after Covid-19. Thus, the favourable assessment of the media performance rose 12 percentage points among people over 65 (Table 8). In contrast, there was no change in the data concerning young people. Although young people increased their consumption of news during the health emergency, the media failed to make young people increase confidence in the news coverage. On the other hand, the data indicate that as the age increased, favourable assessment of the media role during the Coronavirus outbreak increased. This fact did not happen before the start of this crisis. to access the news (\%)
Table 9. Positive assessment of media coverage based on citizens' education (\%)

\begin{tabular}{|l|l|l|l|}
\hline \multicolumn{1}{|c|}{ Education } & Pre-Covid-19 & \multicolumn{1}{c|}{ Covid-19 } & \multicolumn{1}{c|}{ Difference } \\
\hline High school or less & 57 & 73 & +16 \\
\hline Some college & 65 & 65 & 0 \\
\hline College graduate & 71 & 70 & -1 \\
\hline Postgraduate & 78 & 72 & -6 \\
\hline Total U.S. adults & 66 & 70 & +4 \\
\hline
\end{tabular}

Table 10. Positive assessment of the media coverage based on the platform that citizens use

\begin{tabular}{|l|c|c|c|}
\hline \multicolumn{1}{|c|}{ Platform } & Pre-Covid-19 & Covid-19 & Difference \\
\hline Print & 76 & 75 & -1 \\
\hline Network TV & 79 & 82 & +3 \\
\hline Cable TV & 66 & 75 & +9 \\
\hline Social media & 58 & 64 & +6 \\
\hline Website or app & 67 & 62 & -5 \\
\hline Total U.S. adults & 66 & 70 & +4 \\
\hline
\end{tabular}

Regarding education, an increase of 16 percentage points was registered in the positive assessment of the Covid-19 media coverage among people with lower educational standards (Table 9). This group gave more credibility to the media during this health crisis than others. Interestingly enough, people with higher education reduced their confidence in the media coverage of the Coronavirus outbreak. Thus, people with postgraduate education reduced their positive assessment by 6 percentage points. Given that these citizens consumed more news, it can be deduced that the heavy users had a much more critical assessment of the Covid-19 media coverage, as opposed to users with lower educational standards.

The analysis of the platform to access the information shows that the legacy media presented higher percentages of citizens satisfied with the Covid-19 news coverage. Thus, network TV (82\%) followed by cable TV and print media (75\% in both cases) led citizens confidence in information about the health emergency (Table 10). Digital media (websites and social media) were in a lower position with percentages of $62 \%$ and $64 \%$ respectively. Websites and apps suffered a reduction by 5 percentage points of positive assessment from users on the coverage of Coronavirus outbreak. Thus, citizens who access online news relied less on the media and were more negative in assessing the Covid-19 coverage.

\author{
Network TV (82\%) followed by cable TV \\ and print media (75\% in both cases) led \\ citizens confidence in information about \\ the health emergency
}

\subsection{Citizens' ability to detect fake news about the Covid-19}

The worldwide spread of the virus came together with a large circulation of fake news. As of mid-April 2020, the CoronaVirusFact Alliance database, powered by the Poynter Institute and the International Fact-Checking Network, recorded 3,800 Coronavirus-related hoaxes circulating worldwide. 500 of them in the United States. https://www.poynter.org/coronavirusfactsalliance

Disinformation thus became a phenomenon closely linked to the spread of Covid-19. We will not study these rumours and falsehoods here, or the fact-checking activity to discover them, though we will analyse the citizens' perception of the fake news linked to this pandemic.

Citizens' ability to detect news that seemed completely made-up grew during the Coronavirus outbreak. In particular, it increased by 12 percentage points. Before the health crisis, 35\% of Americans claimed to have seen this type of information. After the start of the declaration of the state of emergency, this figure rose to $47 \%$ of the population. This implies that almost half of the citizens found fake news about the pandemic. The data indicate the increase in disinformation perceived by citizens coinciding with Covid-19.

Considering the news engagement of citizens, we can see that, if we compare the data before and after the outbreak, the largest increase in detecting fabricated news occurred in the group of people least connected to the news. These groups experienced an increase of 24 percentage points, going from $22 \%$ to $46 \%$ (Table 11). However, despite registering the smallest increase, the citizens most committed to the news presented the highest detection values for hoaxes. The data indicate that the higher the level of news engagement, the higher the percentage of people who detect fake news both before and after the Covid-19 crisis. 
A similar trend is observed when analysing the variable of attention to the news. During the national health emergency, the number of people who found falsehoods increased in the groups with lower levels of news consumption, and that was less close to the news. The group least aware of the news experienced a growth of 31 points (table 12). From that point onwards, the Covid-19 caused a progressive rise in the percentages of citizens detecting fake news as they were more connected to the news. It is significant to note that the group of citizens most attentive to the news experienced a 5-point decline during the health crisis. Despite this, the data reveal that while attention to the news increases, the percentage of citizens who detect made-up news is higher, though the differences between the different variables are minimal.

In the sociodemographic variables we can see interesting results. The analysis of age shows that the youngest age-ranges are the ones that most increased their ability to detect fake news due to the Coronavirus outbreak. These registered growths of 23 and 20 percentage points (Table 13). On the contrary, people aged 65 and over reduced their percentage by one point. These data generate a relevant finding: young people go from being the ones who discover a lower percentage of made-up news before the crisis, to being the group that finds the most hoaxes with the arrival of the pandemic. The same is true, but in reverse, with a group of people over 65 years of age. Thus, Covid-19 caused a radical change in the previously established trend. Before, as age increased, the percentage of people who discovered false information grew. However, after the event, as age increased, this percentage decreased.

With reference to education, the largest increase in detecting fake news occurred in the groups with the lowest educational standards (17 and 12 percentage points, respectively). Citizens' capacity to detect fake news diminished as the educational level rose (Table 14). Citizens with a medium-low level of education ("some college" category) presented the highest percentage of hoax detection. The data show that the percentage of people able to find made-up news does not grow as citizens' education increases.

Lastly, considering the platform used for news, social media users discovered falsehoods about the Covid-19 in a higher percentage. $52 \%$ of these citizens found made-up news during the health crisis (Table 15). This represents an increase of 25 percentage points in comparison to the previous days. This substantial increase may indicate that social media became the main circulation channel for fake news during the Coronavirus outbreak. On the opposite extreme, only $37 \%$ of print media users found hoaxes, being the group with the lower percentage. In general, the percentages of citizens who detected falsehoods about the Covid-19 were higher in digital media (social media and websites or apps) than in legacy

Table 11. Detection of fake news based on citizens' engagement to the news (\%)

\begin{tabular}{|l|c|c|c|}
\hline \multicolumn{1}{|c|}{ News engagement } & Pre-Covid-19 & Covid-19 & Difference \\
\hline News influencers & 50 & 52 & +2 \\
\hline News bystanders & 39 & 48 & +9 \\
\hline Those checked out of news & 22 & 46 & +24 \\
\hline Total U.S. adults & 35 & 47 & +12 \\
\hline
\end{tabular}

Table 12. Detection of fake news based on citizens' attention to the news (\%)

\begin{tabular}{|l|c|c|c|}
\hline \multicolumn{1}{|c|}{ Attention to the news } & Pre-Covid-19 & Covid-19 & Difference \\
\hline Very closely & 53 & 48 & -5 \\
\hline Somewhat closely & 37 & 49 & +12 \\
\hline Not too closely & 26 & 47 & +21 \\
\hline Not at all closely & 15 & 46 & +31 \\
\hline Total U.S. adults & 35 & 47 & +12 \\
\hline
\end{tabular}

Table 13. Detection of fake news based on citizens' age (\%)

\begin{tabular}{|l|c|c|c|}
\hline \multicolumn{1}{|c|}{ Age } & Pre-Covid-19 & Covid-19 & Difference \\
\hline $18-29$ & 30 & 53 & +23 \\
\hline $30-49$ & 31 & 51 & +20 \\
\hline $50-64$ & 37 & 43 & +6 \\
\hline $65+$ & 44 & 43 & -1 \\
\hline Total U.S. adults & 35 & 47 & +12 \\
\hline
\end{tabular}

Table 14. Detection of fake news based on citizens' education (\%)

\begin{tabular}{|l|c|c|c|}
\hline \multicolumn{1}{|c|}{ Education } & Pre-Covid-19 & Covid-19 & Difference \\
\hline High school or less & 31 & 48 & +17 \\
\hline Some college & 38 & 50 & +12 \\
\hline College graduate & 36 & 45 & +9 \\
\hline Postgraduate & 37 & 45 & +8 \\
\hline Total U.S. adults & 35 & 47 & +12 \\
\hline
\end{tabular}

Table 15. Detection of fake news based on the platform that citizens use to access the news (\%)

\begin{tabular}{|l|c|c|c|}
\hline \multicolumn{1}{|c|}{ Platform } & Pre-Covid-19 & Covid-19 & Difference \\
\hline Print & 39 & 37 & -2 \\
\hline Network TV & 33 & 42 & +9 \\
\hline Cable TV & 44 & 46 & +2 \\
\hline Social media & 32 & 57 & +25 \\
\hline Website or app & 37 & 49 & +12 \\
\hline Total U.S. adults & 35 & 47 & +12 \\
\hline
\end{tabular}


media (print media, national open television, and cable television). These data reveal how legacy media have a greater capacity to successfully conduct fact-checking and data verification tasks, further limiting the circulation of rumours and fake news, as opposed to the digital environment.
The data suggest that the increased consumption of news about Coronavirus did not translate into a significant increase in trust towards the media

\section{Discussion and conclusions}

The data demonstrate that, in critical situations of high complexity and risk to human life, such as the Coronavirus outbreak, citizens consider the search for information and the following of news as key activities. As a result, news consumption increases enormously. In the case of Covid-19, 92\% of adults in the United States frequently accessed the news about the pandemic, registering an increase of 32 percentage points over the period before the health emergency. This extraordinary growth demonstrates that information is, at certain times, a highly valuable resource for citizens. Consequently, the Coronavirus outbreak has involved acknowledgment of journalism as an essential instance in 21st-century societies. In this case, the data, both on consumption and on the assessment of journalistic coverage concerning credibility, reaffirm the high social relevance of the media system in our world at critical moments.

Our findings constitute an innovative contribution to explain how the media system works during highly relevant public affairs. The most important discovery is that the Covid-19 has served those citizens furthest away and less interested in the news to reconnect with the information about public affairs. The largest increase in news consumption and positive assessment of the media coverage on the pandemic occurred in the type of users who were previously unrelated to the news, such as young people, uneducated people, and occasional consumers of information.

The Coronavirus outbreak has caused the percentages to grow exceptionally in these social groups in comparison to the situation before the start of the health crisis. This has reduced the differences between the least informed citizens and those who previously had higher values (heavy users, people over 65, and with high educational standards). Therefore, Covid-19 has partially reduced the existing inequalities regarding news consumption among citizens, equalising citizens' access and informative practices, and generating positive consequences for democracy. Activating the news consumption of the most disconnected citizens, the health crisis has promoted the principle of intrinsic equality (Dahl, 2006), and has stimulated the principle of general access to information (Habermas, 2006). Consequently, it has revitalised interest in public affairs, reviving the public sphere.

Likewise, the data allow us to affirm the predominance of legacy media in highly critical situations, such as the Covid-19 crisis. These media obtain higher percentages both in news consumption and in the positive assessment of news coverage, linked to credibility and trust in the media. In a complex and risky information context, the public opts for established information sources with a long history. In particular, television is the medium with the highest levels of consumption and credibility. This shows that has assumed a high centrality in the political information environment (Esser et al., 2012) during the Coronavirus outbreak. Despite its decline in recent years, the impact of the Covid-19 crisis reveals that television, together with the rest of legacy media, have regained their preponderance as social ties (Wolton, 1990) in the transmission of news about the health crisis. Almost the entire social community gathered in front of the screen to receive valuable information.

The primacy of legacy media during the Coronavirus outbreak partly challenges certain theories that defend how these media are reducing their influence in today's political information environment, at least in the event of highly disruptive situations. In the present health crisis, legacy media have reclaimed their right to be heard, recovering part of their journalistic authority (Carlson, 2017). Their centrality in news consumption and the credibility of the public during the Covid-19 also questions their displacement as preferred sources of current affairs (Bennett; Pfetsch, 2018). Furthermore, it partially disputes the claim that they have lost prominence as a place from which citizens attribute relevance and significance to current events (Williams; Delli-Carpini, 2011). In this sense, we could affirm that the Coronavirus outbreak has restored part of the journalistic authority to legacy media, amid a period of strong crisis of its role in the media system. The question is whether this will be a parenthesis or a change in trend in the immediate future.

Third, the data show the hybrid nature of the media system nowadays (Chadwick, 2017). Despite legacy media having the highest percentages of news consumption and trust, digital media (websites and social media) experience significant increases compared to the period before the health crisis. This manifests the fully established symbiotic coexistence between old and new media. The results even suggest the existence of a dynamic of media complementarity (Dutta-Bergman, 2004). The high percentages of consumers obtained by the different media seem to
Legacy media obtain higher percentages both in news consumption and in the positive assessment of news coverage, linked to credibility and trust in the media 
indicate that many people have employed various platforms simultaneously to find out about the evolution of the Coronavirus outbreak. However, further studies are necessary to confirm this conclusively.

Finally, Covid-19 demonstrates the limits of social media to inform about highly relevant public affairs. Despite the growth experienced by these media to access the news in recent years (Newman et al., 2019), the data demonstrate that they do not succeed in displacing the legacy media as a priority source of information during the health crisis. Social media are also below the average coverage rating in terms of credibility. Besides, the results indicate that people who use social media to inform themselves detect fake news related to the virus in a higher percentage. This reveals that these digital platforms have become the main channel for the circulation of fabricated news about the pandemic. These results are in line with previous works that had detected limitations of social media when generating interest and political knowledge about public affairs among citizens (Gil de Zúñiga; Diehl, 2019; Lee; Xenos, 2019).

Although having an exploratory nature, these findings evidence the existence of the influence of Covid-19 on the media system. The impact of the Coronavirus outbreak on the news consumption has reinforced certain trends already present in the political information environment. But it has also exposed the emergence of important developments such as the resurgence of legacy media, especially television, and the reconnection of citizens who normally remain disconnected from the news. These processes have potential benefits for democracy. However, we require new studies to find out whether Covid-19 has been able to improve the levels of information of citizens to enhance their civic engagement while facing a critical high-risk situation.

\section{Referencias}

Barlovento Comunicación (2020). Cambio de hábitos y preferencias de la ciudadanía española frente al televisor por la crisis del coronavirus. Informe especial, marzo 2020.

https://www.barloventocomunicacion.es/wp-content/uploads/2020/04/Informe-especial-coronavirus-MARZO-2020ACTUALIZADO.pdf

Bennett, W. Lance; Livingston, Steven (2018). "The disinformation order: Disruptive communication and the decline of democratic institutions". European journal of communication, v. 33, n. 2, pp. 122-139.

https://doi.org/10.1177/0267323118760317

Bennett, W. Lance; Pfetsch, Barbara (2018). "Rethinking political communication in a time of disrupted public spheres". Journal of communication, v. 68, n. 2, pp. 243-253.

https://doi.org/10.1093/joc/jqx017

Carlson, Matt (2017). Journalistic authority: Legitimating news in the digital era. New York: Columbia University Press. ISBN: 9780231174459

Casero-Ripollés, Andreu (2018). "Research on political information and social media: Key points and challenges for the future". El profesional de la información, v. 27, n. 5, pp. 964-974.

https://doi.org/10.3145/epi.2018.sep.01

Casero-Ripollés, Andreu (2020). "Influence of media on the political conversation on Twitter: Activity, popularity, and authority in the digital debate in Spain". Icono14. Revista científica de comunicación y tecnologías emergentes, v. 18, n. 1, pp. 33-57.

https://doi.org/10.7195/ri14.v18i1.1527

Chadwick, Andrew (2017). The hybrid media system: Politics and power. Oxford: Oxford University Press. ISBN: 9780 190696733

Dahl, Robert A. (2006). On political equality. New Haven: Yale University Press. ISBN: 9780300126877

Dutta-Bergman, Mohan J. (2004). "Complementarity in consumption of news types across traditional and new media". Journal of broadcasting \& electronic media, v. 48, n. 1, pp. 41-60.

https://doi.org/10.1207/s15506878jobem4801_3

Esser, Frank; De-Vreese, Claes H.; Strömbäck, Jesper; Van-Aelst, Peter; Aalberg, Toril; Stanyer, James; Lengauer, Günther; Berganza, Rosa; Legnante, Guido; Papathanassopoulos, Stylianos; Salgado, Susana; Sheafer, Tamir; Reinemann, Carsten (2012). "Political information opportunities in Europe: A longitudinal and comparative study of thirteen television systems". The international journal of press/politics, v. 17, n. 3, pp. 247-274.

https://doi.org/10.1177/1940161212442956

European Broadcasting Union (EBU). Covid-19 Crisis. PSM Audience performance. March 2020.

https://www.ebu.ch/publications/research/membersonly/report/covid-19-crisis-psm-audience-performance 
Feenstra, Ramón A.; Tormey, Simon; Casero-Ripollés, Andreu; Keane, John (2016). La reconfiguración de la democracia. Granada: Comares. ISBN: 9788490454411

Gfk (2020). Tracking semanal Covid-19 España. Píldora 4.

https://www.gfk.com/fileadmin/user_upload/dyna_content/ES/documents/GfK_COVID19_PILDORA_4.pdf

Gil de Zúñiga, Homero; Diehl, Trevor (2019). “News finds me perception and democracy: Effects on political knowledge, political interest, and voting". New media \& society, v. 21, n. 6, pp. 1253-1271.

https://doi.org/10.1177/1461444818817548

Gil de Zúñiga, Homero; Huber, Brigitte; Strauß, Nadine (2018). "Social media and democracy". El profesional de la información, v. 27, n. 6, pp. 1172-1180.

https://doi.org/10.3145/epi.2018.nov.01

Gil de Zúñiga, Homero; Weeks, Brian; Ardèvol-Abreu, Alberto (2017). "Effects of the news-finds-me perception in communication: Social media use implications for news seeking and learning about politics." Journal of computer-mediated communication, v. 22, n. 3, pp. 105-123.

https://doi.org/10.1111/jcc4.12185

Habermas, Jürgen (2006). "Political communication in media society: Does democracy still enjoy an epistemic dimension? The impact of normative theory on empirical research". Communication theory, v. 16, n. 4, pp. 411-426.

https://doi.org/10.1111/j.1468-2885.2006.00280.x

Koblin, John (2020). "The evening news is back". The New York Times, March 24.

https://www.nytimes.com/2020/03/24/business/media/coronavirus-evening-news.html

Kovach, Bill; Rosenstiel, Tom (2007). The elements of journalism: What newspeople should know and the public should expect. New York: Three Rivers Press. ISBN: 9780307346704.

Lee, Sangwon; Xenos, Michael (2019). "Social distraction? Social media use and political knowledge in two US Presidential elections". Computers in human behavior, v. 90, pp. 18-25.

https://doi.org/10.1016/j.chb.2018.08.006

Newman, Nic; Fletcher, Richard; Kalogeropoulos, Antonis; Nielsen, Rasmus Klein (2019). Reuters Institute digital news report 2019. Oxford: Reuters Institute for the Study of Journalism.

https://reutersinstitute.politics.ox.ac.uk/sites/default/files/2019-06/DNR_2019_FINAL_0.pdf

Van-Aelst, Peter; Strömbäck, Jesper; Aalberg, Toril; Esser, Frank; De-Vreese, Claes H.; Matthes, Jörg; Hopmann, David; Salgado, Susana; Hubé, Nicolas; Stępińska, Agnieszka; Papathanassopoulos, Stylianos; Berganza, Rosa; Legnante, Guido; Reinemann, Carsten; Sheafer, Tamir; Stanyer, James (2017). "Political communication in a high-choice media environment: a challenge for democracy?". Annals of the International Communication Association, v. 41, n. 1, pp. 3-27. https://doi.org/10.1080/23808985.2017.1288551

Waisbord, Silvio (2018). "Truth is what happens to news: On journalism, fake news, and post-truth". Journalism studies, v. 19, n. 13, pp. $1866-1878$.

https://doi.org/10.1080/1461670X.2018.1492881

Williams, Bruce A.; Delli-Carpini, Michael X. (2011). After broadcast news: Media regimes, democracy, and the new information environment. Cambridge: Cambridge University Press. ISBN: 9780521279833

Wolton, Dominique (1990). Eloge du grand public: une théorie critique de la télévision. Paris: Flammarion. ISBN: 9782 080664570

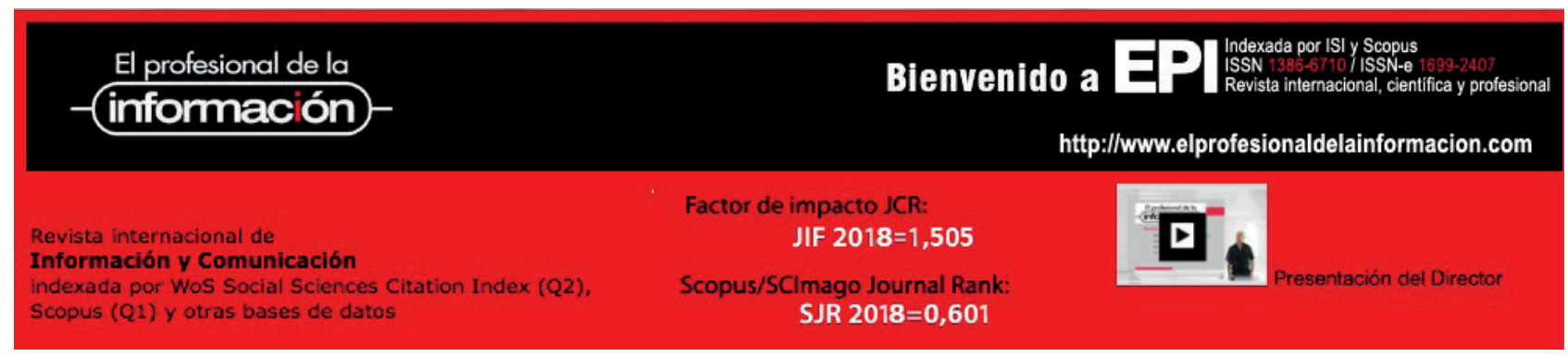

